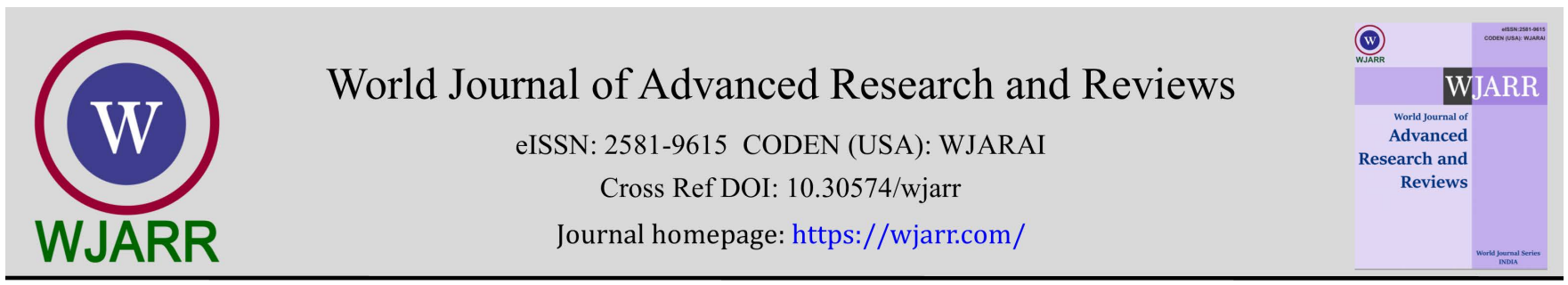

(REVIEW ARTICLE)

\title{
Pharmacological benefits of plant extract of Peperomia pellucida growing wild in Suburb of Bandar Lampung, Indonesia
}

\author{
Mohammad Kanedi * \\ Department of Biology, Faculty of Mathematics and Sciences, University of Lampung, Bandar Lampung, Indonesia.
}

World Journal of Advanced Research and Reviews, 2022, 13(02), 519-522

Publication history: Received on 18 January 2022; revised on 20 February 2022; accepted on 22 February 2022

Article DOI: https://doi.org/10.30574/wjarr.2022.13.2.0177

\begin{abstract}
Peperomia pellucida (L.) is an herbaceous plant belonging Piperaceae family believed by traditional communities in many Southeast Asian countries including Indonesia as a medicinal plant efficacious for treating various diseases. This traditional belief has also been strengthened by various pharmacological and phytochemical research findings. However, pharmacological research on this plant is still limited to common diseases. Therefore, we conducted research to examine other pharmacological properties of the plant that are abundantly growing wild in the suburbs of Bandar Lampung. As a result, Peperomia pellucida plant extract has benefits in promoting hair growth, ameliorating male libido, recovering male fertility, and ameliorating renal cells damages.
\end{abstract}

Keywords: Suruhan; Peperomia Pellucida; Medicinal Benefits; Hair Growth; Sperm Parameter; Male Libido

\section{Introduction}

Peperomia pellucida (L.) called 'suruhan' in Indonesia is an herbaceous plant belonging to Piperaceae family. In many Southeast Asian countries including Indonesia, this plant was believed to be efficacious for treating several diseases such as diabetes, muscle pain, aches, common cold and fever [1]. Pharmacological study reports revealed this plant possess antipyretic, analgesic, anti-inflammatory, antimicrobial, refrigerant, antioxidant, antihyperglicemia, ant hyperuricemia, burn healing, depressant effect, gastro protective, hypotensive, cytotoxic, ant sickling cell, lipase inhibitory, fibrinolytic and thrombolytic, antidiarrheal, and ant osteoporotic activities. In addition, there are also claims that the suruhan plant also has cosmetic benefits [2-4].

Phytochemical studies reports showed that plant extract of Peperomia pellucida (L.) is rich in mineral content such as sodium, potassium, calcium, zinc, iron, manganese, lead and phosphorus. [5,6]. In addition to minerals, this plant also known to contain many bioactive substances such as stigma sterol, [7]; -amino acid, $\alpha$, alkaloid, glycoside, reducing sugar, flavonoid, tannin, steroid, terpenoid, neutral compound, phenolic compound and starch [8]; $\beta$-caryophyllene, $\alpha$ humulene, epi- $\alpha$-bisabolol, sabinene, crypt one and caryophyllene oxide. [9]

In the city of Bandar Lampung, the capital of Lampung province, located in the southernmost part of Sumatra, this plant grows wild in the suburbs and is very easy to find. However, studies on the medicinal properties of this plant other than those already believed and practiced by the local community are still very limited. For this reason, we have investigated the pharmacological properties of this plant beyond those already known to local people and medicinal plant researchers.

\footnotetext{
${ }^{*}$ Corresponding author: Mohammad Kanedi

Department of Biology, Faculty of Mathematics and Sciences, University of Lampung, Bandar Lampung, Indonesia. 
The pharmacological properties of the Peperomia pellucida plant extract that we obtained and published in the 20172021 period are: promote hair growth, ameliorate male libido, recover male fertility, and ameliorate renal cells damages.

\section{Hair-growth promoting activity}

The hair growth promoting activity of Peperomia pellucida was revealed from experiment done by Kanedi et al (2017). In this experiment, Peperomia pellucida plant extract was prepared in the form of a topical gel using CMC. The gel was applied to the skin of the shaved rabbit twice a day, for 21 days. Topical CMC gel containing ethanolic plant extracts of suruhan significantly increase the animal hairs length in a concentration-related manner. However, in comparison to both negative and positive controls, suruhan plant extracts show no significant effect on hair mass of the animals. It suggests that ethanolic plant extract of Peperomia pellucida is potent to be used as the topical formulations for hair growth [10].

We suspect, this effect arises because Peperomia pellucida plant extracts contain a high-value mineral composition comprising potassium, calcium and iron as the main elements that make this weed would serve as a good source of protein and energy as well as micronutrients that allow this plant extracts to affect hair growth [11].

\section{Male libido ameliorating activity}

Pharmacological benefits of Peperomia pellucida in ameliorating male libido was found by Kanedi et al. (2019) from giving this plant extract to alloxan-induced diabetic male mice using glibenclamide as a comparison, the positive control. Results showed plant extracts of suruhan significantly lowering blood glucose levels, shortening courtship and mounting latency, as well as increasing mounting frequency of the mice. It suggests that plant extract of suruhan is potent to be used as anti-hyperglycemic and libido enhancing agents in male subjects [12].

The most important findings of this study is the recovery of the sexual dysfunction of test mice suffering from hyperglycemia by treatment of ethanol extract of Peperomia pellucida plant. The active ingredient of this plant that is thought to play a role in the recovery of libido in hyperglycemic mice is piperine. It has been revealed that black pepper extracts, another type of plant belongs to Piperaceae family containing piperine, effectively increase sexual drive-in male mice [13-14].

\section{Male fertility recovering activity}

Medicinal efficacy of Peperomia pellucida in recovering male fertility was revealed by Kanedi et al., (2019) from investigating effects of plant extracts of suruhan (Peperomia pellucida L. Kunth) on the blood glucose level and sperm parameters in male mice with alloxan-induced hyperglycemia. Extract treatment for 35 days on alloxan-induce hyperglycemia male mice significantly lowering blood glucose levels, ameliorate sperms count, viability, motility, and morphology. Based on this data it suggests that plant extract of Peperomia pellucida is potential to be used as antidiabetic and male fertility recovery agents [15].

Besides being proven to be effective in reducing blood sugar levels, plant extracts of suruhan, have also been proven to effectively restore male fertility parameters in mice with alloxan-induced hyperglycemia. The efficacy of plant extract of suruhan against the infertility of male mice with hyperglycemia can be associated with the presence of minerals and bioactives mentioned above. It has been indicated that phenolic compounds (phenols, sterol, lignans and flavonoids, vitamins, folic acid, bio-trace elements ( $\mathrm{Ca}, \mathrm{Mg}, \mathrm{P}, \mathrm{Zn}, \mathrm{K}, \mathrm{Cu}$ and $\mathrm{Fe}$ ), most of the essential amino acids, volatile oils, polyphenols and saponins have positive effects on sperm motility, count, and viability [16].

\section{Recovering activity on renal histological abnormality}

The study aimed to determine whether suruhan plant (Peperomia pellucida) claimed to have anti-diabetic properties, can improve renal histological abnormalities in alloxan-induced hyperglycemic mice was done by Kanedi et al. (2021) Results showed that plant extract of suruhan significantly reduced histological abnormalities of renal tubular and glomerular cells. So that it suggests plant extract of suruhan is potent to be used as anti hyperglycemic agent and diabetes-related complication [17]. 
The findings of this study indicate that the histological damage to renal tubules and glomerulus of mice due to alloxan injection has recovered by the treatment of plant extract of $P$. pellucida. This fact indicates the functioning of the antioxidant compounds in this plant extract [18-19].

\section{Conclusion}

The pharmacological findings that we obtained confirm that the claims of traditional communities in many tropical countries about the medicinal benefits of the plant Peperomia pellucida (L.) are not exaggerated. These findings also strengthen the pharmacological assumption which states that this herbaceous plant belonging to the Piperaceae family contains a variety of bioactive substances.

\section{Compliance with ethical standards}

\section{Acknowledgments}

I would like to acknowledge Ms.Titin Aprilia, Ms. Eti Purwanti and Ms. Indah Yusni for their inspirational supports.

\section{Competing interest}

Author declared there is no competing interest.

\section{References}

[1] Susilawati Y, Nugraha R, Krishnan J, Muhtadi A, Sutardjo S,Supratman U. A New Antidiabetic Compound 8.9dimethoxy Ellagic Acid from Sasaladaan (PeperomiapellucidaL. Kunth). Research Journal of Pharmaceutical. Biological and Chemical Sciences. 2017; 8(1S): 269-274.

[2] Kartika I GAA, Insanu M, Safitri D,Putri CA, Adnyana IK. New Update: Traditional Uses. Phytochemical. Pharmacological and Toxicity Review of Peperomia pellucida (L.) Kunth. Pharmacology OnLine. 2016; 31: 30-43.

[3] Majumder P, Abraham P. Satya V. Ethno-medicinal. Phytochemical and Pharmacological review of an amazing medicinal herb Peperomia pellucida (L.) HBK. RJPBCS. 2011; 2(4):358-364.

[4] Narayanaswamy R, Ismail IS. Cosmetic potential of Southeast Asian herbs: an overview. Phytochem Rev. 2015; 14:419-428.

[5] OoiDJ, Iqbal S, Ismail M. Proximate Composition. Nutritional Attributes and Mineral Composition of Peperomia pellucida L. (Ketumpangan Air) Grown in Malaysia. Molecules. 2012; 17: 11139-11145.

[6] Ojo 00, Ajayi SS, Owolabi LO. Phytochemical screening. Anti-nutrient composition. Proximate analyses and the antimicrobial activities of the aqueous and organic extracts of bark of Rauvolfiavomitoria and leaves of Peperomia pellucida. International Research Journal of Biochemistry and Bioinformatics. 2012;2(6):127-134.

[7] Hartati S, Angelina M, Dewiyanti I,danMeilawati L. Isolation and Characterization Compounds From Hexane and Ethyl Acetate Fractions of Peperomia pellucida L. The Journal of Tropical Life Science.September 2015; 5(3): 117 122.

[8] Htet YM. Sabai, Khaing MM. Botanical Studies and Phytochemical Screening of Peperomia pellucida (L.) Kunth (Thit-YayGyi). Hinthada University Research Journal. 2016; 7(1).

[9] Lira PDL, Farfán Y, van Baren CM, Bandoni AL, Coussio JD, de Abram AP. Composition of the essential oil of two Peperomia from Peru: P. Galioides and P. Chalhuapuquiana Rev. Latinoamer. Quím. 2007; 35/1: 7-12.

[10] Kanedi M,Lande ML,Nurcahyani N,Anggraeni IR,Yulianty. Hair-growth promoting activity of plant extracts of suruhan (Peperomiapellucida) in Rabbits. IOSR Journal of Pharmacy and Biological Sciences (IOSR-JPBS. 2017; 12(5 Ver VI): 18-23.

[11] Ooi D.J., Iqbal S. and Ismail M. Proximate Composition, Nutritional Attributes and Mineral Composition of Peperomia pellucida L. (Ketumpangan Air) Grown in Malaysia . Molecules 2012, 17, 11139-11145; doi:10.3390/molecules170911139

[12] Kanedi M, Sutyarso, Busman H, Kesuma CI, Yulianty, Lande ML. Ameliorative Effect of Plant Extracts Of Suruhan (PeperomiaPellucida) On Blood Glucose and Libido of Male Mice Injected With Alloxan. European Journal of Biomedical and Pharmaceutical Sciences. 2019; 6(2): 18-21. 
[13] Ahmad I., Rissyelly, Kurniawan A. and Mun'im A. Screening of Extraction Method for Alkaloid Enrichment Of Peperomia pellucida (L.) Kunth. Asian J Pharm Clin Res, 2017; 10(70: 214-219. DOI: http://dx.doi.org/10.22159/ajpcr.2017.v10i7.18246.19.

[14] Sutyarso, Kanedi M. and Rosa E. Effects of Black Pepper (Piper nigrum Linn.) Extract on Sexual Drive in Male Mice. Research Journal of Medicinal Plant, 2015; 9(1): 42-47. DOI: 10.3923/rjmp.2015.42.47.

[15] Kanedi M, Sutyarso, Busman H. Mandasari RA and Pratami GD. Plant extracts of Suruhan (PeperomiapellucidaL. Kunth) ameliorate infertility of male mice with alloxan-induced hyperglycemia. International Journal of Biomedical Research. 2019; 10(2): 1-4.

[16] Mohammadi F., Nikzad H., Taherian A., Mahabadi J.A. and Salehi M. Effects of Herbal Medicine on Male Infertility. Anatomical Sciences, 2013; 10(4): 3- 16.

[17] Kanedi M, Mumtazah DF,Purwanti E. Ameliorative Effect of Plant Extract of Suruhan (Peperomiapellucida) on Renal Histological Abnormality in Alloxan-Induced Hyperglycemic Mice. South Asian Res J Pharm Sci. May-Jun 2021; 3(3): 40-43.

[18] Xu, S., Li, N., Ning, M. M., Zhou, C. H., Yang, Q. R., \& Wang, M. W. (2006). Bioactive compounds from peperomia p ellucida. Journal of natural products, 69(2), 247-250.

[19] Narayanamoorthi, V., Vasantha, K., \& Maruthasalam, R. R. A. A. (2015). GC MS determination of bioactive components of Peperomia pellucida (L.) Kunth. Bioscience Discovery, 6(2), 83-88. 